\title{
Islam and Democracy in the Middle East
}

Larry Diamond, Marc F. Plattner, and Daniel Brumberg, eds. Baltimore and London: The Johns Hopkins University Press, 2003. 322 pages.

This collection of essays edited by Larry Diamond, Marc F. Plattner, and Daniel Brumberg, is one that everyone interested in future of the Middle 
East should read carefully. All of the essays here, in one way or another, seek to address that most perplexing of questions: Why has the Middle East so stubbornly resisted the sweeping reach of democracy? The answers presented are sometimes illuminating and, even in the weaker sections, almost always thought provoking.

All of the authors in this volume come from the basic and - I hope fairly self-evident assumption that sustained democratic change is now an imperative of the highest order. What is so interesting about this collection is the diversity of viewpoints and the alternating currents of pessimism and optimism that run through it. For the most part, the authors rarely delve into the kind of neo-conservative posturing that obscures a nuanced understanding of the interplay between political Islam and democratization. There are some unfortunate exceptions, such as Ladan and Roya Boroumand's embarrassing assertion that Hassan al-Banna "borrowed the idea of heroic death as a political art form,” while Emmanuel Sivan commits a surprising factual error when he posits that the Sudanese Islamist regime is an example of "one man, one vote, one time."

Islam and Democracy in the Middle East starts off, somewhat curiously, with a bizarre piece from Mohamed Talbi, a Tunisian historian. His essay, "A Record of Failure,” is really nothing more than an extended rant about the depressing state of the Arab world. However, it is nonetheless fascinating for its unapologetic tone of hopelessness and resignation that so accurately mirrors the sentiments of so many in the region. Other authors, in the first of three sections entitled "Democratization in the Arab World," argue that contrary to what appearances may suggest, many Arab countries are not only stagnating insofar as real, structural change is concerned, but are actually regressing in some respects. In "The Trap of Liberalized Autocracy," Brumberg argues that top-down democratization often becomes little more than a tool with which to manage and co-opt the opposition as well as absorb popular anger. Jason Brownlee (writing on Egypt) and Russell E. Lucas (writing on Jordan) point out that after promising openings, both countries have backtracked and effectively suspended their experiments with democracy.

Michael Herb, in "Emir and Parliaments in the Gulf," sees grounds for optimism in the Gulf monarchies, particularly in Kuwait, where "elections matter" and the Parliament "has substantial legislative powers." But despite these "openings," after reading the chapters on the Arab world, one is left with the impression that democracy is not going to come any time soon.

The second section focuses exclusively on Turkey and Iran. There are six separate essays discussing Iran's precarious power struggle between 
theocratic hardliners and the increasingly marginalized reformists. Haleh Esfandiari's description of the days leading up to the once-thought-to-be historic 2000 parliamentary elections is moving, and, therefore, all the more tragic - yet another reminder of what the Middle East could be if the aspirations of its people were actually respected and channeled.

Amid the depressing circumstances in the Arab world and Iran, Turkey may well prove - if Prime Minister Tayyip Erdogan continues with his bold program of reforms - to be the democratic model for the rest of the region. The authors of the two essays on Turkey seem to agree. Soli Ozel makes the case that the Islamists, after the "post-modern coup" of 1997 and the repression of the late 1990s, "awoke from the experience with a newfound appreciation of democratic principles and a systematic resolve - the first ever in their movement's history - to embark on a principled quest to defend not merely their own liberties, but democratic liberties as such." And indeed, Erdogan's Justice and Development Party, in an ironic twist, has become one of the most pro-EU, pro-West, pro-democracy party in Turkish history.

The third and last section, "Islam and Democracy," concentrates on the interplay among religion, modernity, and liberalism. Abdou Filali-Ansary, a Moroccan secularist who contributes three essays in this section, puts forward the culturalist argument that the "updating of religious conceptions" is an essential condition for achieving democracy. This kind of rhetoric, which Bernard Lewis echoes in his own essay, posits that Islam is the ultimate problem and that democracy can only come about if there is first a religious "reformation." Radwan Masmoudi makes the reverse argument in his essay: Islamic thought in the Arab world has been stifled by an undemocratic atmosphere in which people, lacking the means to engage in free and unfettered debate, are not exposed to alternative opinions on issues of national importance.

The problem with Filali-Ansary, as each of his three essays clearly illustrate, is that he is a "democrat" who seems to have little respect for the fact that the democratic majority is, at least theoretically, in support of something that he feels is, in the first place, antithetical to the very notion of democracy. For him, there is the democratic alternative and then there is the Islamic alternative. He apparently does not realize that in the context of the Arab world, they may in fact be one and the same thing.

In the end, while the authors do an excellent job of analyzing, deconstructing, and diagnosing the Middle East's democracy deficit, there is not much in the way of solutions offered. Considering that Egypt and Jordan, 
once thought to be harbingers of Arab democracy, have fallen into the "trap of liberalizing autocracy," it has become increasingly difficult to envision how real democracy will ever actually come about in the region. To their credit, Brumberg and Vickie Langohr see a major role for the United States in using foreign aid to pressure intransigent Arab regimes to move forward with real reforms. Unfortunately, however, no essay in this collection analyzes in any great depth how American foreign policy has and continues to affect, often negatively, the process of democratization in the Middle East.

Although it is clear that the authors have made an effort to be objective, they sometimes appear unable to hide their gut aversion to Islamists - the group, for better or worse, most likely to benefit from democratic openings. Brumberg, in "Islamists and the Politics of Consensus," asks: "Will Islamists share power with groups that espouse alternative notions of political community?" It is worth asking why there is always an a priori assumption that Islamists, even moderate, non-violent ones, are somehow innately more hostile to democracy than their secular counterparts, especially considering that most Arab dictatorships of the last five decades have been secular.

Despite the aforementioned concerns, the fact that this volume raises so many vital, urgent questions is a testament to the editors' careful hand in guiding this project. Moreover, this book lends only more evidence that Brumberg - and his handprints are all over this volume - is quickly becoming the foremost scholar on democratization in the Middle East. Although far from perfect, Islam and Democracy in the Middle East is one of the most comprehensive and informative surveys on the subject published thus far. 